\title{
Worldwide Introduction of North American Pawpaw (Asimina triloba): Evidence Based on Scientific Reports
}

\author{
Robert G. Brannan ${ }^{1} \&$ Maria N. Coyle ${ }^{1}$ \\ ${ }^{1}$ Division of Food and Nutrition Sciences, Ohio University, Athens, Ohio, USA \\ Correspondence: Robert G. Brannan, Division of Food and Nutrition Sciences, Ohio University, Athens, Ohio \\ 45701, USA. Tel: 740-592-2879. E-mail: brannan@ohio.edu
}

Received: April 7, 2020 Accepted: April 30, 2021 Online Published: May 3, 2021

doi:10.5539/sar.v10n3p19 URL: https://doi.org/10.5539/sar.v10n3p19

\begin{abstract}
The North American pawpaw (Asimina triloba) is a small tree native to the Appalachian region of the United States that produces large, yellowish-green to brown fruit that has the flavor of a banana and mango. The scope of this review is limited to pawpaw orchards outside of North America that were intentionally planted for commercial or research purposes and are documented in the scientific literature. This review identified nine countries outside of North America (Romania, Italy, Ukraine, Slovakia, Austria, Georgia, Russia, Japan, Korea) and across two continents that have scientific literature that describes pawpaw cultivation. There are reports that pawpaws are cultivated in China, Israel, Belgium, and Portugal, however, no scientific literature could be found that describes pawpaw research from these countries. Most of the research since 2010 has featured pawpaws grown in Romania, Italy, and Korea with a focus on characterizing roots, twigs, leaves, pulp and seeds or the toxicity and/or bioactivity of the annonaceous acetogenins naturally found in these parts of the pawpaw.
\end{abstract}

Keywords: Asimina triloba, North American pawpaw, pawpaw

\section{Introduction}

Asimina triloba [L.] Dunal, known as the North American pawpaw or simply the pawpaw, is a deciduous tree native to the Appalachian region of the United States. The growing region of the pawpaw includes the temperate regions of USDA Hardiness Zones 5-9, which includes almost all of the eastern half of the United States and portions of southern Ontario, Canada. Pawpaw trees thrive in floodplains and shady bottomlands and multiple trees often cluster into a "pawpaw patch." Pawpaw trees can grow to a height of $11 \mathrm{~m}$. The large leaves of pawpaw trees are clustered symmetrically at the ends of the branches. Common parts of the pawpaw tree are depicted in Figure 1. Pawpaw fruit is large, yellowish-green and has the flavor of a banana and mango (Brannan et al., 2012). There are many regional names for the pawpaw in North America. Worldwide the pawpaw is often confused with the unrelated tropical papaya fruit (Carica papaya), also called "pawpaw."
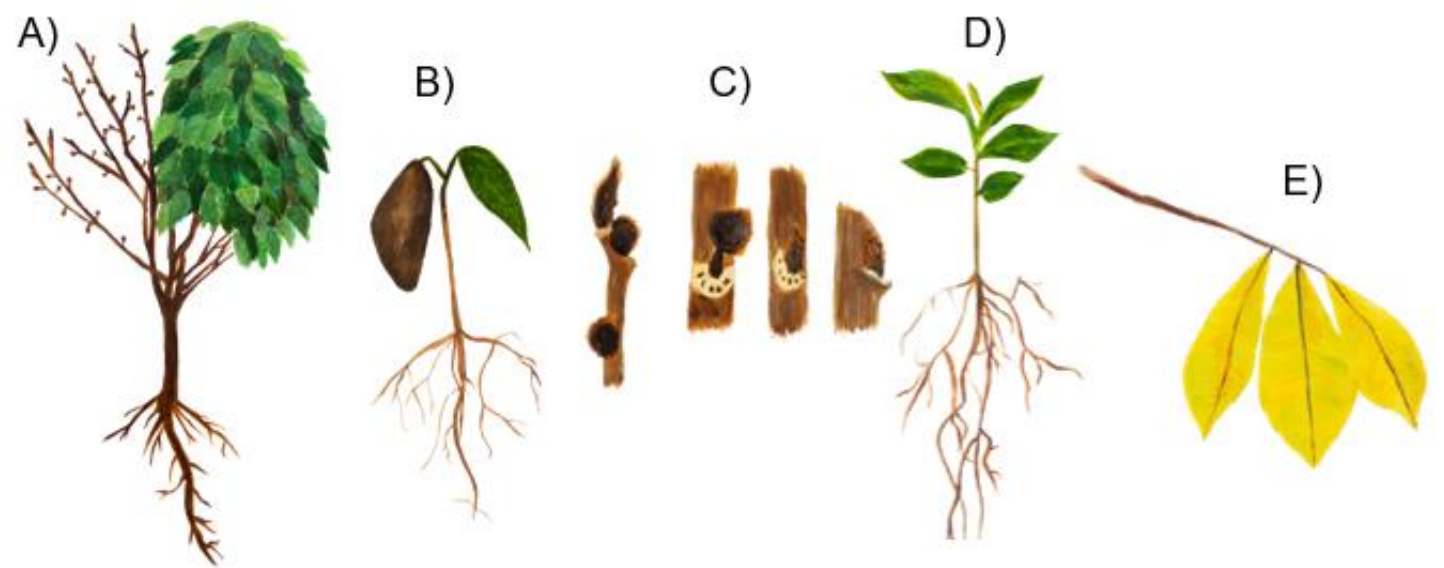

Figure 1. Artists rendition of A) the pawpaw tree (Asimina triloba); B) a seedling; C) a winter terminal bud with flower bud; D) a sapling; and E) a fall leaf (Artwork @ by author M.N. Coyle) 
The origin of the pawpaw is believed to be ancient. Fossils of Asimina triloba found in North America suggest it has existed for more than 50 million years (Moore, 2015). There is speculation that early North Americans may have cultivated pawpaw (Hormaza, 2014) and the name of the fruit's scientific genus, Asimina, is thought to have been adapted from the native American word assimin, which means berry or fruit in the language of the Powhatan from eastern Virginia USA, an indigenous Algonquian group that existed before European colonization. Early information about pawpaw comes from England in 1736 from a registry at the Cambridge University Botanic Garden, which has a collection of pawpaw from North American germplasm (Cambridge Botanic Garden, 2021). There is evidence that the pawpaw helped provide food for the Lewis and Clark expedition as they headed west across the North American continent in September of 1806 (Moulton, 1997). Documentation exists that famous historical Americans such as the third US president Thomas Jefferson, frontiersman Daniel Boone, and author Mark Twain were devotees of the pawpaw. There are reports that wild stands of pawpaw provided food for runaway slaves and American Civil War soldiers when rations ran low (Moore, 2015). At the turn of the $20^{\text {th }}$ century, pawpaw was identified by the American Horticultural Society as a fruit of promising potential and were sold in cities and towns in areas where the trees naturally grew (Ragan, 1888; Reich, 1991). Today there are American towns and rivers named after the fruit. In the early part of the $20^{\text {th }}$ century, wild pawpaw selections were cultivated in orchards leading to the naming of 56 pawpaw clones, but fewer than 20 of those original selections survived due to abandonment and neglect. After 1960, an effort was made to add additional cultivars from the wild and developed through breeding (Jones et al., 1998). Today, there are a wide number of varieties available.

This review is focused on pawpaw orchards outside of North America that were intentionally planted for commercial or research purposes and are documented in the scientific literature. It is likely that pawpaw collections exist in many more botanical gardens outside of North America than those covered in this work, however,

\section{Europe}

\subsection{Romania}

Romania has been the source of a significant amount of pawpaw research from outside of North America. Historically, the first report of pawpaw in Romania comes from the small village of Pianu Nou in Alba County (Transylvania), in northwestern Romania. In 1926, a Romanian immigrant family brought seeds from Toledo, Ohio. In 2000, Romanian scientists began examining propagation techniques, orchard management and plant behavior and reported positive results (Stănică et al., 2006). There are now 9 significant collections across the country (Stanica, 2016). One of these locations, Baia Mare (Maramures County) was the focus of work that reported promising acclimatization of pawpaw into the region (Szilagyi et al., 2014; Szilagyi \& Marian, 2011). Soon after, characterization of the first Romanian pawpaw genotype was reported (Stanica, 2012) along with information about the decedents of those plants that were planted in the Bucharest Faculty of Horticulture fields in 2000. Results of a six-year study provided valuable morphological information in relation to the climate conditions encountered (Szilagvi et al., 2016b). More recently, the flowering characteristics of Romanian pawpaws have been characterized with a particular focus on the effects of climate change (Szilagvi et al., 2016a, 2017). Recent research has described the pawpaw as one of the most exotic plants that was adapted in Romania and was optimistic about its market potential (Ivan et al., 2020).

\subsection{Italy}

Pawpaw plantings in Italy have a long history. Asimina triloba was first planted at the Botanical Garden in Padua in 1801 (Meyer, 1959). More recently, commercial plantings of pawpaw in Italy were initiated in 1983 in Faenza and the Horticulture Department of the University of Florence began studying these pawpaw in 1990, focused on development of new varieties (Bellini \& Montanari, 1992). By 2000, this orchard became the largest Italian pawpaw orchard and collection (Bellini et al., 2003) and the pawpaw commercialization efforts were being targeted towards Italian hobbyists and amateurs (Bellini \& Montanari, 2000). Fourteen cultivars of American origin and a cultivar of Italian origin named Prima 1216 were evaluated a few years later (Bellini et al., 2003). Work at the University of Torin on pawpaws grown in Torin Province led to the development of a "chemical fingerprint" of the pawpaw via the assessment of the chemical composition and antioxidant activity of Asimina triloba at different ripening stages (Donno et al., 2014).

\subsection{Ukraine}

The body of work concerning pawpaw in Ukraine largely is reported in the Ukranian language, so locating and then interpreting the work is challenging for an English-speaking author. Pawpaws were reported as a new fruit in the south of Ukraine in 2002 (Derevyanko et al., 2002). A 2007 work described the nutrients and bioactive 
compounds of pawpaw fruits, leaves, and shoots grown in Ukraine (Polonskaya et al., 2007). As important as this work is to the body of knowledge of pawpaw, the same article describes the introduction of pawpaw into Ukraine (translated):

"The introduction of Asimina triloba (L.) Dunal began in 1919, when several plants of different ages first appeared among the plantings of the Garden. In 1939, according to F.K. Kalayids, the diameters of the trunks of these plants were $16 \mathrm{~cm}$, and the area of their crowns was $5 \times 5 \mathrm{~m}$. They were characterized by good growth and annual fruiting. Unfortunately, in 1994, the Asimina plants died as a result of an abnormally dry summer. But in the fall of the same year from the nursery "Northwoods Nursery Inc." (USA) grafted seedlings of the two best varieties of pawpaw three-lobed Prolific and Sunflower were obtained. Plants were planted on the site of the Department of Subtropical Fruit and Nut Crops of the Garden, and in 1996 the first pawpaw plantings were made in the Novokakhovskoye NBS Experimental Farm. Every year, over the course of ten years, the gene pool of this culture was replenished, and in 2004 the collection transferred to the Novokakhovskoye Production and Production Enterprise totaled 16 varieties of foreign selection and 69 hybrid forms."

Other papers describe Ukrainian pawpaw characteristics including their ecological features (Grabovetzkaya et al., 2006), flavonoid accumulation (Levon \& Klymenko, 2016), growing characteristics (e.g. tree crowning) (Krasovsky, 2016), and morphological characteristics of the species (Pavlova et al., 2019).

\subsection{Slovakia}

In Slovakia, cultivars (AxT-01 to AxT-06) sown in 2000 at the Slovak University of Agriculture in Nitra were used to characterize their morphology, total polyphenol content, total flavonoid content, and antioxidant capacity (Brindza et al., 2019). A single tree of Italian cultivar Prima planted in 2009 in a private garden in Čebovce was used to study Synanthedon tipuliformis, a local pest that could affect the pawpaw (Kollar \& Bakay, 2015).

\subsection{Austria}

The Botanical Garden of the University of Vienna has Asimina triloba (L.) Dunal but the origin cannot be identified. Research on the anthers collected from a tree in this collection have been used to study pollen germination (Hesse et al., 2009).

\section{Eastern Europe/Western Asia}

\subsection{Georgia}

Research suggests that pawpaw trees were cultivated in Batumi, a Black Sea resort and port city and the capital of the Georgian republic of Adjara, at the Batumi Botanical garden. The flower buds of these pawpaw trees were used to study the different developmental stages in pawpaw (Gabarayeva, 1992).

\subsection{Russia}

The body of work concerning pawpaws in Russia appears to be significant but is reported in the Russian language, so locating and then interpreting the work is challenging for an English-speaking author. Bibliographic databases report a translated study titled "Ecological and Agrochemical Peculiarities of Cultivation (Asimina triloba, Dunal.) in Russian Subtropics," however the actual citation could not be determined. Russian pawpaws were described at a research conference in 2014 (Khokhlov \& Dunaevskaya, 2014). In 2015, new cultivars were reported based on work from The Russian Research Institute of Floriculture and Subtropical Crops. They characterize these cultivars as having high yield, good fruit quality, and resistance to pests and diseases (Kulyan et al., 2015). The introduction of several of these cultivars (Sochi 11, Sochi 12, Valentina, and others) of pawpaw into the Republic of Adygea in the North Caucasus region of European Russia then was reported (Pchikhachev \& Korzun, 2017). Recently, the biochemical composition and biologically active compounds of Asimina triloba grown in Russia was explored (Klimenko et al., 2019).

\section{Asia}

\subsection{Japan}

It is likely that pawpaw was introduced into Japan in the late $19^{\text {th }}$ century but did not develop as a commercial fruit bearing tree, although it remains a relatively widely planted household fruit tree and the ripe fruit is often sold in fruit shops in October (Shiota, 1991; Tomita \& Kozuka, 1965). Pawpaw appears to be distributed across many Japanese prefectures. The earliest scientific paper that could be found using the search tools of the day appears to be a 1956 paper that describes contemporary research in polyploidy of adult Asimina triloba plants and two year old seedlings that were grow in the botanical garden of Kyoto University, then known as Saikyo University (Ito \& Mutsuura, 1956). The Kyoto University botanical garden likely is the source of pawpaws for 
other studies as well (Hatakeyama et al., 1973). Pawpaws from other parts of Japan have also been used for scientific study. For example, pawpaw seeds grown in Hyogo, Tottori and Tokyo prefectures were studied for their potential as a source of edible oil and de-fatted meal (Matsui, 1980).

\subsection{Korea}

As of 2015, it was reported that there was 2.1 cultivated hectares of pawpaw located across 5 Korean provinces (Kim et al., 2019). For several years in the mid-2010's, there was a concerted effort by Korean brokers to introduce pawpaw seeds and scion wood into Korea. Personal communication with one of these brokers at the 2014 Ohio Pawpaw Festival (Ohio, USA) produced an exchange in which the broker explained that there are "millions" of recently planted pawpaw trees in Korea [personal communication]. Within the past few years, several research articles have been produced by Korean scientists, likely due to the boom in pawpaw. Pawpaws obtained from a farm in Okchon, South Korea were used to evaluate some basic antioxidant capacity measurements (Nam et al., 2017). These same researchers performed a much more systematic study on the nutritional value of pawpaw roots, twigs, leaves, fruit pulp, and seeds harvested from the same farm (Nam, Jang, et al., 2018). This excellent study produced information for the proximates and dietary fiber, sugar and organic acids, amino acids, minerals, fatty acids, vitamins $\mathrm{B}, \mathrm{C}, \mathrm{E}$, and $\beta$-carotene. This same research group characterized phenolic compounds, antioxidant capacity, and antimicrobial activity on pawpaws from Cheongyang, South Korea (Nam et al., 2019). Recently there has been work characterizing the toxicity and/or bioactivity of the Annonaceous acetogenins naturally found in different parts of the pawpaw (Im \& Lee, 2018; Nam, Park, et al., 2018).

\section{Summary}

Several of the studies contained herein have implied that increased interest in pawpaw promotion has led to nurseries in other countries offering pawpaw trees for cultivation and there are botanical gardens around the world that house Asimina triloba in their collections such as the one in Cambridge England (Cambridge Botanic Garden, 2021). It also has been reported that pawpaws are cultivated in China, Israel, Belgium, and Portugal (Pomper \& Layne, 2005).

The recent emergence of pawpaw research centered in Romania and Korea suggests that these areas may provide a foothold for the expansion of pawpaw cultivation outside of North America. Both have a temperate-continental climate with hot summers, cold winters, and very distinct seasons, climate conditions characteristic for the Appalachian region of the United States where pawpaws flourish. It will be interesting to observe if the demand and consumption of pawpaw as a specialty produce item produces a grower base that can support commercialization. As with the North American market, it will be imperative for commercialization efforts to focus on pawpaw fruit with strong market potential. The market potential outside of North American likely is to be defined by similar factors as in the niche North American market, namely that the fruit be firm with a creamy texture, strong tropical flavor and aroma, and low bitterness (Brannan et al., 2012), which are all important factors in consumer acceptance (Brannan et al., 2012).

\section{References}

Bellini, E., \& Montanari, D. (1992). La coltura dell'Asimina in Italia. (The cultivation of Asimina in Italy.). L'Informatore Agrario, 45, 51-64.

Bellini, E., \& Montanari, D. (2000). Asimina triloba, a reality for Italian amateur fruit growing. Rivista di Frutticoltura e di Ortofloricoltura, 62(1), 54-61.

Bellini, E., Nin, S., \& Cocchi, M. (2003). Characterization of some cultivars of Asimina triloba 1. Cultivated in Italy. Hortechnology, 13(5), 455-457. https://doi.org/10.21273/HORTTECH.13.3.0455

Brannan, R. G., Salabak, D. E., \& Holben, D. H. (2012). Sensory analysis of pawpaw (Asimina triloba) pulp puree: Consumer appraisal and descriptive lexicon. Journal of Food Research, 1(1), 179. https://doi.org/10.5539/jfr.v1n1p179

Brindza, J., Grygorieva, O., Klymenko, S., Vergun, O., Mareček, J., \& Ivanišová, E. (2019). Variation of fruits morphometric parameters and bioactive compounds of Asimina triloba (L.) Dunal germplasm collection. Potravinarstvo Slovak Journal of Food Sciences, 13(1), 1-7. https://doi.org/10.5219/1019

Cambridge Botanic Garden. (2021). Asimina Triloba. Retrieved from https://www.botanic.cam.ac.uk/the-garden/plant-list/asimina-triloba/

Derevyanko, N. V., Derevyanko, V. N., \& Hokhlov, S. Y. (2002). Asimina triloba L. - a new fruit culture of the south of Ukraine Vista Biosphere Reserve "ASKANIYA-NOVA (Vol. 4). 
Donno, D., Beccaro, G. L., Mellano, M. G., Cerutti, A. K., \& Bounous, G. (2014). Chemical fingerprinting as nutraceutical quality differentiation tool in Asimina triloba L. Fruit pulp at different ripening stages: An old species for new health needs. Journal of Food \& Nutrition Research, 53(1), 81-95.

Gabarayeva, N. I. (1992). Sporoderm development in Asimina triloba (Annonaceae). Grana, 31(3), 213-222. https://doi.org/10.1080/00173139209432033

Grabovetzkaya, O. A., Derevyanko, V. N., \& Khokhlov, S. Y. (2006). Papaw (Asimina triloba (L.) Dun.): Being and prospects of culture, biological and ecological features in the south of Ukraine. Plant Introduction, 31, 21-25.

Hatakeyama, I., Murata, G., \& Tabata, H. (1973). A List of Plants in the Botanical Garden of Kyoto University and Some Ecological Data. Memoirs of the Faculty of Science, Kyoto University. Series of Biology, 6(2), 91-148.

Hesse, M., Halbritter, H., \& Weber, M. (2009). Beschorneria yuccoides and Asimina triloba (L.) Dun: Examples for proximal polar germinating pollen in angiosperms. Grana, 48(3), 151-159. https://doi.org/10.1080/00173130903024343

Hormaza, J. I. (2014). The pawpaw, a forgotten North American fruit tree. Arnoldia, 72(1), 13-23.

Im, D.-Y., \& Lee, K. I. (2018). Utilization of liquid chromatography mass spectroscopy for screening analysis of acetogenins in extracts of Asimina triloba leaves. Korean Journal of Pharmacognosy, 49(3), 278-284.

Ito, I., \& Mutsuura, O. (1956). Studies on the induced polyploids of the North American Pawpaws (I): Chromosome number and mixoploids in Asimina triloba DUNAL. The Scientific Reports of the Saikyo University. Agriculture, 8, 57-60.

Ivan, E. Ş., Nițu, O. A., Jerca, I. O., \& Stănică, F. (2020). Preliminary results regarding the postharvest pathology of pawpaw (Asimina triloba Dunal) fruits. Scientific Papers-Series B, Horticulture, 64(1), 125-128.

Jones, S. C., Peterson, R. N., Turner, T.-A., Pomper, K. W., \& Layne, D. R. (1998). Pawpaw planting guide. Retrieved March, 14, 2016.

Khokhlov, S. Y., \& Dunaevskaya, E. V. (2014). Biological value of [Asimina triloba (L.) Dunal. In Tropical Issues of Fruit and Decorative Gardening at the Beginning of the XXI Century.

Kim, C.-Y., Kim, Y.-H., Han, S.-H., \& Ko, H.-C. (2019). Current situations and prospects on the cultivation program of tropical and subtropical crops in Korea. Korean Journal of Plant Resources, 32(1), 45-52.

Klimenko, S. V., Kukharska, A. Z., \& Grigorieva, O. V. (2019). Biochemical characteristics and medicinal properties of Asimina triloba (L.) Dunal. Metabolomics and the Quality of Life, 107-113.

Kollar, J., \& Bakay, L. (2015). The Currant Clearwing moth Synanthedon tipuliformis as a new pest for pawpaw (Asimina triloba L.) in Slovakia-short communication. Plant Protection Science, 51(3), 153-155. https://doi.org/10.17221/16/2015-PPS

Krasovsky, V. V. (2016). Some special features of forming crown of (Asimina triloba (L.) Dunal) during introduction in the forest- steppe zone of Ukraine. NUBIP Ukraine Scientific Reports, 59(2), 5. https://doi.org/10.31548/dopovidi2016.02.004

Kulyan, R. V., Ivanchenko, F. K., \& Ksenofontova, D. V. (2015). New varieties of Asimina triloba (L.) Dunal for Russian subtropics. Fruit and Breeding of Russia, 41, 223-227.

Levon, V. F., \& Klymenko, S. (2016). Dynamics of the accumulation of flavonoids in overground organs of cultivars and forms of Asimina triloba (L.) Dunal. Plant Introduction, 2, 77-81.

Matsui, T. (1980). Studies on the utilization of pawpaw seeds as a source of seed oil. Bulletin of the Faculty of Agriculture, Meiji University, Japan, 52, 43-53.

Meyer, F. G. (1959). Plant Explorations: Ornamentals in Italy, Southern France, Spain, Portugal, England, and Scotland (Vol. 9). Agricultural Research Service, US Department of Agriculture. https://doi.org/10.5962/bhl.title.70187

Moore, A. (2015). Pawpaw: In search of America's forgotten fruit. Chelsea Green Publishing.

Moulton, G. E. (1997). The journals of the Lewis and Clark expedition. University of Nebraska Press.

Nam, J.-S., Jang, H.-L., \& Rhee, Y. H. (2017). Antioxidant activities and phenolic compounds of several tissues of pawpaw (Asimina triloba [L.] Dunal) grown in Korea. Journal of Food Science, 82(8), 1827-1833. https://doi.org/10.1111/1750-3841.13806 
Nam, J.-S., Jang, H.-L., \& Rhee, Y. H. (2018). Nutritional compositions in roots, twigs, leaves, fruit pulp, and seeds from pawpaw (Asimina triloba [L.] Dunal) grown in Korea. Journal of Applied Botany Food Quality, 91, 47-55.

Nam, J.-S., Park, S.-Y., Lee, H.-J., Lee, S.-O., Jang, H.-L., \& Rhee, Y. H. (2018). Correlation between acetogenin content and antiproliferative activity of pawpaw (Asimina triloba [L.] Dunal) fruit pulp grown in Korea. Journal of Food Science, 83(5), 1430-1435. https://doi.org/10.1111/1750-3841.14144

Nam, J.-S., Park, S.-Y., Oh, H.-J., Jang, H.-L., \& Rhee, Y. H. (2019). Phenolic profiles, antioxidant and antimicrobial activities of pawpaw pulp (Asimina triloba [L.] Dunal) at different ripening stages. Journal of Food Science, 84(1), 174-182. https://doi.org/10.1111/1750-3841.14414

Pavlova, N. R., Pavlov, V. V., \& Saldetska, A. O. (2019). Characteristic of the anatomical structure of the Asimina triloba L. Природничий Альманах. Серія: Біологічні Науки, 26, 122-131. https://doi.org/10.32999/ksu2524-0838/2019-26-12

Pchikhachev, E. K., \& Korzun, B. V. (2017). Introduction of a pawpaw three-blade (Asimina triloba (L.) Dunal.) in a foothill zone of. Adyghea Bulletin of the Adygea State University, 1, 92.

Polonskaya, A. K., Ezhov, V. N., Khokhlov, S. Y., \& Vinogradov, B. A. (2007). Biologically active substances of asimine three-lasted [Asimina triloba (L.) Dunal. Collection of Scientific Papers of the State Nikitsky Botanical Garden, 12, 200.

Pomper, K. W., \& Layne, D. R. (2005). The North American pawpaw: Botany and horticulture. Horticultural Reviews, 31, 349-382. https://doi.org/10.1002/9780470650882.ch7

Ragan, W. H. (1888). In Southern United States. United States Department of Agriculture Report. pp. 582.

Reich, L. (1991). Uncommon fruits worthy of attention: A gardener's guide. Addison-Wesley.

Shiota, H. (1991). Volatile components of pawpaw fruit (Asimina triloba Dunal). Journal of Agricultural and Food Chemistry, 39(9), 1631-1635. https://doi.org/10.1021/jf00009a019

Stanica, F. (2012). Asimina triloba (pawpaw) germplasm in Romania. Lucran Stiintifice USAMVB. Seria B, 56, 267-272.

Stanica, F. (2016). Pawpaws in Romania. 4th International Pawpaw Conference.

Stănică, F., Cotruţ, R., \& Zuccherelli, G. (2006). New selections of pawpaw (Asimina triloba (L) Dunal). XXVII International Horticultural Congress-IHC2006: International Symposium on Enhancing Economic and Environmental, 772, 203-203. https://doi.org/10.17660/ActaHortic.2008.772.28

Szilagvi, B. A., Stanica, F., \& Dănăilă-Guidea, S. M. (2016a). Flowering of Asimina triloba (L.) Dunal in the conditions of Transylvania. Oltenia Craiova Museum. Oltenia. Studies and Communications. Natural Sciences, 32(1), 50-54.

Szilagvi, B. A., Stanica, F., \& Dănăilă-Guidea, S. M. (2016b). Study the morphology of Asimina triloba (L.) Dunal fruits and seeds obtained in the Transylvania region of Romania. Current Trends in Natural Sciences, 5(9), 79-83.

Szilagvi, B. A., Stanica, F., \& Dănăilă-Guidea, S. M. (2017). Evaluation of morphological parameters of flowering buds and flowering on Asimina triloba (L.) Dunal in the context of climate change in Romania. Current Trends in Natural Sciences, 6(11), 122-127.

Szilagyi, B. A., Dănăilă-Guidea, S. M., \& Marian, M. (2014). Statistical interpretation of some growth parameters for Asimina triloba (L.) Dunal. Romanian Biotechnological Letters, 19(4), 9493.

Szilagyi, B. A., \& Marian, M. (2011). Asimina triloba (L.) Dunal in the context of integrating the species into the Baia Mare urban space. Bulletin of University of Agricultural Sciences and Veterinary Medicine CLUJ-Napoca. Horticulture, 68(1).

Tomita, M., \& Kozuka, M. (1965). Asimina triloba DUNAL alkaloids. Yakugaku Zasshi (Pharmacy), 85(1), 77-82. https://doi.org/10.1248/yakushi1947.85.1_77

\section{Copyrights}

Copyright for this article is retained by the author(s), with first publication rights granted to the journal.

This is an open-access article distributed under the terms and conditions of the Creative Commons Attribution license (http://creativecommons.org/licenses/by/3.0/). 